COMMENT

$\overline{R e c e i v e d ~} 3$ Oct 2016 | Accepted 24 Jan 2017 | Published 21 Feb 2017

DOI: $10.1057 /$ palcomms.2017.8

OPEN

\title{
Soft power: the origins and political progress of a concept
}

Joseph Nye ${ }^{1}$

ABSTRACT Power is the ability to affect others to get the outcomes one prefers, and that can be accomplished by coercion, payment, or attraction and persuasion. Soft power is the ability to obtain preferred outcomes by attraction rather than coercion or payment. This anecdotal comment recounts the origins of the concept as an analytical tool, and its gradual development as an instrumental concept used in political discourse in Europe, China and the United States. This article is published as part of a collection on soft power.

\footnotetext{
${ }^{1}$ University of Harvard, Cambridge, MA, USA
} 
coined the term "soft power" in my 1990 book Bound to Lead that challenged the then conventional view of the decline of American power (Nye, 1990). After looking at American military and economic power resources, I felt that something was still missing-the ability to affect others by attraction and persuasion rather than just coercion and payment. At that time, there was a prevalent belief that the United States was in decline, and Paul Kennedy's The Rise and Fall of the Great Powers was a New York Times best seller (Kennedy, 1987). Kennedy argued that the US was suffering from "imperial overstretch", and would soon go the way of 17 th century Spain or Edwardian Britain. Many others echoed these thoughts, and believed that the Soviet Union was passing us in military might and Japan was overtaking us in economic strength. I doubted this conventional wisdom and went to many seminars and conferences where I was a lonely dissenter.

Both academics and practitioners in international relations tended to treat power as tangible resources you could drop on your foot or drop on a city. This was less true of classical realists like Carr (1939), but particularly true of neorealist theorists such as Kenneth Waltz and his followers who became fashionable in the 1970s (Waltz, 1979). Everything was coercion and payments, but sometimes people influence others by ideas and attraction that sets the agenda for others or gets them to want what you want. Then carrots and sticks are less necessary, or can be used more frugally because others see them as legitimate. With its universalistic values, open culture and vast popular cultural resources ranging from Hollywood to foundations and universities, the United States seemed uniquely placed to affect how others viewed the world and us. Of course, it did not make us attractive to everyone. Quite the contrary, as the Mullahs in Iran proved. But where we were attractive, it was a huge advantage. As one Norwegian scholar put it, if the Americans had created an empire in Europe, it was an "empire by invitation" (Lundestad, 1998). I tried a variety of terms to try to summarize these thoughts, and eventually settled on the term "soft power". I hoped its slightly oxymoronic resonance in the traditional discourse of my field might make people think again about their assumptions when they spoke of power.

I thought of soft power as an analytic concept to fill a deficiency in the way analysts thought about power, but it gradually took on political resonance. In some ways the underlying thought is not new and similar concepts can be traced back to ancient philosophers. Moreover, though I developed the term soft power in the context of my work on American power, it is not restricted to international behaviour or to the United States. As I became interested in leadership studies, I applied the concept to individuals and organizations in my 2008 book The Powers to Lead. (Nye, 2008) Nonetheless, it has taken particular root in international relations, and as the European Union developed, more European leaders began to refer to its soft power. The term was less used, however, by American political leaders.

In 2002, I was one of two keynote speakers at a conference organized by the Army in Washington. I spoke to the assembled generals about soft power and, by their questions, they seemed to get it. Later, one of the generals asked the other keynote speaker, Secretary of Defense Donald Rumsfeld, what he thought of soft power. He replied that he did not understand what soft power meant, and that was evident in his policies. This hubris was evident well before the security drama that followed the terrorist attacks on $9 / 11$, but in that climate of fear, it was difficult to speak about soft power, even though attracting moderates away from appeals by radicals is a key component of any effective counterterrorism strategy.

In that climate, and with the invasion of Iraq proving disastrous, I felt I needed to spell out the meaning of soft power in greater detail. Even colleagues were incorrectly describing soft power as "non-traditional forces such as cultural and commercial goods" and dismissing it on the grounds that "it's, well, soft" (Ferguson, 2009). And a Congresswoman friend told me privately that she agreed 100 per cent with my concept, but that it was impossible to use it to address a political audience who wanted to hear tough talk. In 2004, I went into more detail conceptually in Soft Power: The Means to Success in World Politics. I also said that soft power was only one component of power, and rarely sufficient by itself. The ability to combine hard and soft power into successful strategies where they reinforce each other could be considered "smart power" (a term later used by Hillary Clinton as Secretary of State). I developed the concepts further in my 2011 book on The Future of Power Including in the realm of cyber power (Nye, 2011). I made clear that soft power is not a normative concept, and it is not necessarily better to twist minds than to twist arms. "Bad" people (like Osama bin Laden) can exercise soft power. While I explored various dimensions of the concept most fully in this work, the central definition (the ability to affect others and obtain preferred outcomes by attraction and persuasion rather than coercion or payment) remained constant over time.

In 2007, as the situation in Iraq continued to deteriorate, John Hamre, Richard Armitage and I co-chaired a "Smart Power Commission" for the Centre for Strategic and International Studies in Washington. With former senators and Supreme Court justices participating, we hoped to use soft and smart power for the political purpose of centring American foreign policy. Subsequently in the Bush Administration, in 2007 Secretary of Defense Robert Gates called for the United States to invest more in soft power. It was a long way from the modest ambitions for the analytic concept scribbled out on my kitchen table 17 years earlier. The term "smart power" (the successful combination of hard and soft power resources into effective strategy) was clearly prescriptive rather than just analytical.

Even more impressive in terms of distance from that kitchen table was the fate of the concept in China. As China dramatically developed its hard power resources, leaders realized that it would be more acceptable if it were accompanied by soft power. This is a smart strategy because as China's hard military and economic power grows, it may frighten its neighbours into balancing coalitions. If it can accompany its rise with an increase in its soft power, China can weaken the incentives for these coalitions. In 2007, Chinese President Hu Jintao told the 17th Congress of the Chinese Communist Party that they needed to invest more in their soft power, and this has been continued by the current President Xi Jinping. Once the top leader had spoken and the word was out, billions of dollars were invested to promote soft power, and thousands of articles were published on the subject. China has had mixed success with its soft power strategy. Its impressive record of economic growth that has raised hundreds of millions of people out of poverty and its traditional culture have been important sources of attraction, but polls show it lags behind the United States in overall attractiveness in most parts of the world, including Asia. Portland-a consultancy in London that constructs an annual index of soft power-ranks the United States first and China as number 28 of the top 30 countries (Portland Communications and Facebook, 2016).

Top level endorsement in China affected me directly. Hardly a week went by in the year after Hu Jintao's use of the concept without an e-mail asking me to write an article or participate in some soft power seminar or conference. Chinese officials contacted me for private conversations about how to increase China's soft power. My advice was always the same. I say that China should realize that most of a country's soft power comes from its civil society rather than from its government. 
Propaganda is not credible and thus does not attract. China needs to give more leeway to the talents of its civil society, even though this is difficult to reconcile with tight party control. Chinese soft power is also held back by its territorial disputes with its neighbours. Creating a Confucius Institute to teach Chinese culture in Manila will not generate attraction if Chinese naval vessels are chasing Philippine fishing boats out of Scarborough Shoal that lies within 200 miles of its coastline. When I said this on a televised panel at Davos in 2013, Wang Jianglin, the richest man in China interrupted the panel to criticize me for "hurting the feelings of the Chinese people".

One of the most intriguing occasions was an invitation to address the School of Marxism at Peking University in Beijing. I was treated royally. When it came time for my lecture to some 1500 students, I was seated alone at a table on a podium covered with gorgeous flowers with a large screen on the wall behind me with an enlarged video of my performance. In the course of my speech, I addressed the question of how China could increase its soft power and I mentioned the harassment of the great Chinese artist Ai WeiWei as an example of too tight control over civil society. There was a slight titter in the crowd, but at the end of my lecture, the dean of the School of Marxism took the stage and gave a long flowery thanks that author of the concept of soft power had come to address the school. As he went on, however, I noted that my translator was skipping much of what he said. I later asked a Mandarin-speaking Canadian friend who was present in the front row what the dean had said. In summary: "we are flattered to have Professor Nye here, but you students must realize that his use of the concept is overly political and we prefer to restrict it to cultural issues."

With time, I have come to realize that concepts such as soft power are like children. As an academic or a public intellectual, you can love and discipline them when they are young, but as they grow they wander off and make new company, both good and bad. There is not much you can do about it, even if you were present at the creation. As the Princeton political scientist
Baldwin (2016) has recently written, "Nye's discussion of soft power stimulated and clarified the thoughts of policy makers and scholars alike-even those who misunderstood or disagree with his views". Perhaps that is all one can hope for.

\section{References}

Baldwin DA (2016) Power and International Relations: A Conceptual Approach. Princeton University Press: Princeton, NJ.

Carr EH (1939) The Twenty Years' Crisis, 1919-1939: An Introduction to the Study of International Relations. Palgrave Macmillan: London.

Ferguson NC (2009) Think again: power. Foreign Policy(March-April): 18-24.

Kennedy PM (1987) The Rise and Fall of the Great Powers: Economic Change and Military Conflict from 1500 to2000. Random House: New York.

Lundestad G (1998) "Empire" by Integration: The United States and European Integration, 1945-1997. Oxford University Press: Oxford.

Nye JS Jr (1990) Bound to Lead: The Changing Nature of American Power. Basic Books: New York

Nye JS Jr (2008) The Powers to Lead. Oxford University Press: Oxford.

Nye JS Jr (2011) The Future of Power. Public Affairs: New York.

Portland Communications and Facebook. (2016) "The Soft Power 30 Report", http://softpower30.portland-communications.com/wp-content/themes/soft power/pdfs/the_soft_power_30.pdf, accessed 12 January 2017.

Waltz KN (1979) Theory of International Politics. Addison-Wesley: Reading, MA.

\section{Additional information}

Competing interests: The author declares no competing financial interests.

Reprints and permission information is available at http://www.palgrave-journals.com/ pal/authors/rights_and_permissions.html

How to cite this article: Nye J (2017) Soft power: the origins and political progress of a concept. Palgrave Communications. 3:17008 doi: 10.1057/palcomms.2017.8.

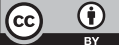

This work is licensed under a Creative Commons Attribution 4.0 International License. The images or other third party material in this article are included in the article's Creative Commons license, unless indicated otherwise in the credit line; if the material is not included under the Creative Commons license, users will need to obtain permission from the license holder to reproduce the material. To view a copy of this license, visit http://creativecommons.org/licenses/by/4.0/
} 